\title{
Sodium Hypochlorite Provokes Stress Response in Rainbow trout: Variation in Blood Parameters as an Ecotoxicological Indicator of Freshwater Contamination
}

\author{
Sodyum Hipokloritin Gökkuşağı Alabalıklarında Strese Sebep \\ Olması: Tatlı Su Kirlenmesinin Ekotoksikolojik Göstergesi Olarak \\ Kan Parametrelerindeki Varyasyonu
}

Research Article

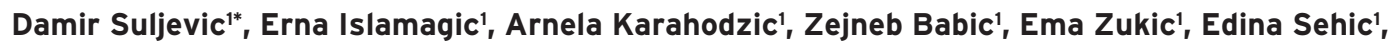
Subha Dzafic ${ }^{2}$, Andi Alijagic ${ }^{1}$

${ }^{1}$ Faculty of Science, Department for Biology, Univeristy of Sarajevo, Sarajevo, Bosnia and Herzegovina.

${ }^{2}$ Biotechnical Faculty, University of Bihac, Bosnia and Herzegovina.

\section{A B S TR AC T}

$\mathrm{n}$ this study we analyzed the effects of $\mathrm{NaOCl}$ solution on blood hematological and biochemical parameters of the rainbow trout Oncorhynchus mykiss (Walbaum, 1792). The treatment lasted for three days with prior dechlorination of the water. Significant differences in the concentration of $\mathrm{K}^{+}, \mathrm{Ca}^{+}, \mathrm{Cl}^{-}$, proteins, glucose were detected and the largest variations were found for creatinine concentration $(P<0.05)$. Significant differences were found for PCV, Hb concentration, RBC, WBC, MCH, MCHC, LYM (\%), SEG (\%) and NEU (\%) values (P<0.05). Small doses of $\mathrm{NaOCl}$ alter the acid-base balance, suggesting a very low-level adaption in the rainbow trout.

\section{Key Words}

Blood parameters, chlorine, rainbow trout, sodium hypochlorite.

\section{öz}

u çalışmada NaOCl çözeltisinin Gökkuşağı balığı Oncorhynchus mykiss (Walbaum, 1792) kanı üzerindeki hematolojik ve biyokimyasal etkileri analiz edildi. Suyun daha önceden klorlanması ile tedavi üç gün sürdü. $\mathrm{K}^{+}, \mathrm{Ca}^{2+}, \mathrm{Cl}^{-}$, proteinler, glikoz konsantrasyonunda önemli farklılıklar tespit edildi ve en büyük varyasyonlar kreatinin konsantrasyonu için bulundu ( $\mathrm{P}<0.05)$ PCV, Hb konsantrasyonu, RBC, WBC, MCH, MCHC, LYM (\%) SEG (\%) ve NEU (\%) değerleri açısından anlamlı fark bulundu (P<0.05). NaOCl'in küçük dozlarının, asit-baz dengesini değiştirmesinden dolayı gökkuşağı alabalığına çok düşük seviyede adaptasyonu olduğunu gösterdi.

\section{Anahtar Kelimeler}

Kan parametreleri, klor, gökkuşağı alabalığı, sodyum hipoklorit.

Article History: Received: May 16, 2018; Revised: Jul 6, 2018; Accepted: Oct 8, 2018; Available Online: Nov 13, 2018.

Dol: 10.15671/HJBC.2018.263

Correspondence to: D. Suljevic, Department for Biology, Faculty of Science, Sarajevo, Bosnia and Herzegovina. 


\section{INTRODUCTION}

$\mathrm{M}$ any chemicals with low toxicity for mammals and birds are very toxic to freshwater species, especially for fish. Fish are exposed to many chemical substances that can cause a stressful reaction. Many studies have revealed that when toxic substances are in the water, the physiological response is reflected in changes of the value of one or more hematological parameters [1]. Repeated exposure to small stressors can lead to weaken neuroendocrine and metabolic responses, like increasement in cortisol concentration [2]. However, the fish response to stress could be considered as an adaptive mechanism that allows them to deal with stress in order to maintain their homeostasis [3]. The most common forms of chlorine found in water are $\mathrm{HOCl}, \mathrm{OCl}^{-}, \mathrm{NH}_{2} \mathrm{Cl}$ and $\mathrm{NHCl}_{2}$. Fish reaction after exposing to chlorine, takes place in several stages, while the first is displaying anxiety and swallowing of the air from the surface [4].

The hypochlorite ion establishes a balance with hydrogen ions and hypochloric acids when chlorine is added to water, when increasing $\mathrm{pH}$ [5]. The biocidal efficiency of chlorine depends on the amount of hypochloric acid $(\mathrm{HOCl})$ in water, because it can penetrate into the cell and react with cellular enzymes [6]. Evans et al. [7] showed that chlorine is dispersed by vascular gill surfaces and affects the central nervous system. The same authors showed that chlorine has influence on gland tissue and directly enters in the cells. Grothe and Eaton [8] found that in fish as in bacteria, chlorine dioxide oxidizes the iron from hemoproteins and consequently inhibits the transport of oxygen [9].

It is assumed that chlorine diffusion flows through the gastric cells to the blood and thus influences the functions of blood in fish [10]. On the other hand, the relationship between $\mathrm{NaOCl}$ toxicity and water temperature was established. Mussel mortality at a concentration of $\mathrm{NaOCl}$ of $5 \mathrm{mg} / \mathrm{L}$ was higher at $20^{\circ} \mathrm{C}$ (mortality $60 \%$ ) than at $12^{\circ} \mathrm{C}$ (mortality $14 \%$ ). There are a relatively small number of studies that investigate effects of $\mathrm{NaOCl}$ on freshwater organisms [11].

The aim of the present study was to analyze effects of low chlorine concentrations on hematological and biochemical parameters of the Oncorhynchus mykiss species in order to understand the adaptive physiological response after exposing to this chemical pollutant.

\section{MATERIALS and METHODS \\ Animals}

In this study, 20 specimens of rainbow trout (control=10; experimental=10) weighing between 176 and $282 \mathrm{~g}$ were used. Individuals were cultivated for commercial purposes. All individuals were originated from the fisheries "Neretva fish" Konjic (Ljuta River). All techniques and methods for fish transport and experimental design were applied in accordance with the Declaration of Animal Rights (UNESCO, 1978), the Universal Declaration on Animal Welfare (WSPA, 2000) and the Animal Protection and Welfare Law of Bosnia and Herzegovina ("Sluzbeni glasnik" 25/09).

\section{Analysis of Residual Chlorine and Dechlorination of Water}

Determination of the residual chlorine was done by the addition of potassium iodide and $1 \%$ starch solution. Based on the colored complex, the concentration of chlorine $(\mathrm{mg} / \mathrm{L})$ in water was determined. Dechlorination of water was performed by adding sodium thiosulphate at a concentration of $5 \mathrm{~g} / \mathrm{m}^{3}$ of aerated water [12]. Water aerating was carried out using the oxygen aerator CHAMPIONICX-0098. The water temperature in the pools was maintained at $15^{\circ} \mathrm{C}$. Both groups were kept separately in different aquariums with a capacity of $100 \mathrm{~L}$ for two days in dehlorinated water. In tank with the experimental group of animals, chlorine was added in the water as $\mathrm{NaOCl}$ solution in the final concentration of 2.5 $\mathrm{mg} / \mathrm{L}$. The treatment lasted in total for three days.

\section{Hematology Techniques and Analysis}

Blood sampling for hematological parameters was performed by direct cardiac puncture using a 1.2 $\mathrm{mm}$ sterile needle (Medoject, Slovak Republic). For hematologic parameters, whole blood was used by adding EDTA as anticoagulant. In order to analyse biochemical parameters, blood was centrifuged at $2500 \mathrm{rpm}$ for $10 \mathrm{~min}$ (Heraeus Sepatech Biofuge model 1217, Germany) and serum was isolated. Following hematological parameters were analysed: number of 
erythrocytes (RBCs) $\left(10^{12} / I\right)$, packed cell volume $(P C V)(I / I)$, hemoglobin concentration $(\mathrm{Hb})(\mathrm{g} / \mathrm{l})$, mean corpuscular hemoglobin (MCV) $(\mathrm{fl})$, mean corpuscular hemoglobin concentration (MCHC) $(\mathrm{g} / \mathrm{l})$, number of leukocytes (WBC) $\left(10^{9} / \mathrm{l}\right)$. The number of RBCs and WBC were determined in Neubauer chamber (Hemocytometer) [13]. Hb was determined by the Drabkin hemoglobin cyanide method by Balasubramaniam \& Malathi (1992) and PCV was determined by a microhematocrit method after centrifugation (Hettich Haematocrit 24 centrifugal, Germany) at 10,000 rpm for $10 \mathrm{~min}$ [14]. Hematological indexes ( $M C V, M C H$ and $\mathrm{MCHC}$ ) were calculated as the ratio of PCV (HCT), Hb concentration, and RBC. Additionally we analyzed the percentage of leukocytes: lymphocytes (LYM) (\%), monocytes (MON) (\%) and neutrophils granulocytes (NEU) (\%) including segmented (SEG) (\%) and non-segmented granulocytes (NSEG) (\%). The percentile leukocyte ratio was analyzed by manual preparation of blood smear and additional May Grunwald staining method (Semikem, B\&H). The light microscope Olympus BX41 was used to differentiate leukocytes and to obtain photomicrographs.

\section{Analysis of Biochemical Parameters}

Spectrophotometric methods were used for the analysis of serum biochemical parameters (spectrophotometer SPECTRONIC GENESYSTM 20). Total calcium concentration $\left(\mathrm{Ca}^{2+)}(\mathrm{mmol} / \mathrm{L})\right.$ was determined by the CPC method with the o-cresolphthalein complex (SGM, Italy), chloride concentration $\mathrm{Cl}^{-}(\mathrm{mmol} / \mathrm{L})$ with mercury thiocyanate (QCA, Spain) assay, while for sodium concentration $\mathrm{Na}^{+}\left(\mathrm{mmo}^{\prime} / \mathrm{L}\right)$ analysis precipitation method with Mg-uranylacetate was used (Human $\mathrm{GmbH}$, Germany). The alkaline solution with tetraphenylborate was used to analyze the potassium concentration $\mathrm{K}^{+}(\mathrm{mmol} / \mathrm{L})$ (Human $\mathrm{GmbH}$, Germany). In order to determine glucose concentration $(\mathrm{mmol} / \mathrm{L})$, the UV enzymatic method with hexokinase (Glucose liqiudUV, Human $\mathrm{GmbH}$, Germany) was performed; a continuous photometric alkaline picrate method Jaffe method was used for analysis of creatinine concentration ( $\mu \mathrm{mol} / \mathrm{L})$ (Futura System, Italy). The Biuret method was performed for the analysis of total proteins concentrations $(\mathrm{g} / \mathrm{L}$ ) (Semikem, $B \& H)$, and the enzymatic method with glutamate dehydrogenase (GLDH) was used for the serum urea (mmol/L) analysis (Futura System, Italy). Lyophilized serum Humatrol $P$ was used as a control serum (Human GmbH, Germany).

\section{Statistical Analysis}

Descriptive statistics was applied for all parameters using IMB SPSS Statistic 20 (USA). Mean, standard deviation and range were analyzed. Intergroup differences were analyzed using one-way ANOVA and the significance was set at the level of $P<0.05$.

\section{RESULTS}

Results of the values of biochemical parameters in control and experimental group were presented in Table 1. In the experimental group, decrease in the concentration of $\mathrm{K}^{+}$and $\mathrm{Ca}^{2+}$ was detected, while for the other parameters was found increase in concentration. However, concentration of $\mathrm{Na}^{+}$ and urea did not show significant intergroup differences $(P>0.05)$. The highest variations were found for the concentrations of chlorine and creatinine.

Hematological parameters, including the leukocyte profile in peripheral blood, are presented in the Table 2. For the experimental group, an increase in PCV, RBCand WBC counts was found, as well as the percentage of LYM and MON. Other parameters were lower in the experimental group. Values of MCV, MON and NSEG were not significantly different among groups.

Types of blood cells in rainbow trout were represented (shown) in Figure 1. Six types of cells were identified in peripheral blood. Some cells were found in different phases of differentiation, therefore they are classified as mature and immature cells.

\section{DISCUSSION}

The negative effects of chlorine ions as an integral part of many chemical compounds have been known for a long time, however, studies conducted mainly refer to the process of choking in humans and sporadically on the fish's extinction. Our research provides first data on these effects that manifest on hematological and biochemical blood parameters, which at the same time represent the defensive mechanism of the fish on negative external factors. Many studies 
572 | D. Suljevic et al. / Hacettepe J. Biol. \& Chem., 2018, 46 (4), 569-575

Table 1. Biochemical parameters of control and experimental groups of fish.

\begin{tabular}{|c|c|c|c|c|c|}
\hline \multirow[b]{2}{*}{ Parameters } & \multicolumn{2}{|l|}{ Control group } & \multicolumn{2}{|c|}{ Experimental group } & \multirow{2}{*}{$\begin{array}{l}\text { ANOVA } \\
\text { Sig. }\end{array}$} \\
\hline & Mean \pm SD & Range & Mean \pm SD & Range & \\
\hline $\mathrm{K}^{+}$ & & & & & \\
\hline$(\mathrm{mmol} / \mathrm{L})$ & $4.68 \pm 1.59$ & $2.45-6.86$ & $3.76 \pm 0.42$ & $3.18-4.43$ & $0.046 *$ \\
\hline $\mathrm{Na}^{+}(\mathrm{mmol} / \mathrm{L})$ & $173.21 \pm 13.15$ & $151.23-190.28$ & $176.93 \pm 11.71$ & $152.60-192.60$ & 0.256 \\
\hline $\mathrm{Ca}^{2+}(\mathrm{mmol} / \mathrm{L})$ & $2.74 \pm 0.69$ & $1.12-3.45$ & $2.35 \pm 0.16$ & $2.14-2.63$ & $0.047^{*}$ \\
\hline $\mathrm{Cl}^{-}(\mathrm{mmol} / \mathrm{L})$ & $140.41 \pm 18.63$ & $104.76-160.95$ & $178.52 \pm 22.20$ & $144.75-210.50$ & $0.000 *$ \\
\hline $\begin{array}{l}\text { Total proteins } \\
(\mathrm{g} / \mathrm{L})\end{array}$ & $36.88 \pm 3.53$ & $30.80-41.30$ & $70.69 \pm 13.00$ & $54.80-89.51$ & $0.000 *$ \\
\hline Glucose (mmol/L) & $5.73 \pm 0.48$ & $5.15-6.34$ & $9.45 \pm 0.99$ & $7.98-11.20$ & $0.000 *$ \\
\hline $\begin{array}{l}\text { Creatinine ( } \mu \mathrm{mol} / \\
\mathrm{L} \text { ) }\end{array}$ & $47.29 \pm 8.15$ & $30.45-59.60$ & $210.73 \pm 36.85$ & $160.23-265.20$ & $0.000 *$ \\
\hline Urea $(\mu \mathrm{mol} / \mathrm{L})$ & $4.48 \pm 2.42$ & $0.79-8.14$ & $5.64 \pm 2.69$ & $3.26-12.64$ & 0.163 \\
\hline
\end{tabular}

* Statistically significant at $\mathrm{P}<0.05$

Table 2. Hematological parameters of control and experimental groups of fish.

\begin{tabular}{|c|c|c|c|c|c|}
\hline \multirow[b]{2}{*}{ Parameters } & \multicolumn{2}{|l|}{ Control group } & \multicolumn{2}{|c|}{ Experimental group } & \multirow{2}{*}{$\begin{array}{l}\text { ANOVA } \\
\text { Sig. }\end{array}$} \\
\hline & Mean+SD & Range & Mean+SD & Range & \\
\hline PCV (I/I) & $0,42 \pm 0.03$ & $0.38-0.47$ & $0.51 \pm 0.02$ & $0.48-0.53$ & $0.000 *$ \\
\hline $\mathrm{Hb}(\mathrm{g} / \mathrm{l})$ & $88.11 \pm 5.86$ & $79.00-97.65$ & $57.83 \pm 6.67$ & $49.95-74.25$ & $0.000 *$ \\
\hline RBC $\left(10^{12} / \mathrm{I}\right)$ & $1.29 \pm 0.16$ & $1.10-1.50$ & $1.61 \pm 0.21$ & $1.15-1.83$ & $0.001 *$ \\
\hline$M C V(f \mid)$ & $334.33 \pm 48.03$ & 257.89-412.28 & $318.82 \pm 44.07$ & 273.14-417.39 & 0.231 \\
\hline $\mathrm{MCH}(\mathrm{pg})$ & $69.70 \pm 9.16$ & $54.66-81.75$ & $37.03 \pm 10.43$ & $28.54-64.57$ & $0.000 *$ \\
\hline $\mathrm{MCHC}(\mathrm{g} / \mathrm{l})$ & $209.83 \pm 22.64$ & $179.55-256.97$ & $114.68 \pm 15.42$ & $98.12-154.69$ & $0.000 *$ \\
\hline WBC $\left(10^{9} / \mathrm{I}\right)$ & $3.73 \pm 0.30$ & $3.27-4.12$ & $4.42 \pm 0.32$ & $3.85-4.80$ & $0.000 *$ \\
\hline LYM (\%) & $61.60 \pm 8.24$ & $42-71$ & $72.60 \pm 8.76$ & $54-84$ & $0.005^{*}$ \\
\hline MON (\%) & $1.63 \pm 0.74$ & $1-3$ & $2.00 \pm 0.47$ & $1-3$ & 0.105 \\
\hline SEG (\%) & $25.60 \pm 6.15$ & $18-38$ & $15.80 \pm 5.79$ & $10-30$ & $0.001^{*}$ \\
\hline NSEG (\%) & $11.70 \pm 4.79$ & $6-20$ & $9.60 \pm 4.45$ & $2-14$ & 0.162 \\
\hline NEU (\%) & $37.30 \pm 8.54$ & $28-58$ & $25.40 \pm 8.80$ & $14-44$ & $0.003 *$ \\
\hline
\end{tabular}

* Statistically significant at $\mathrm{P}<0.05$

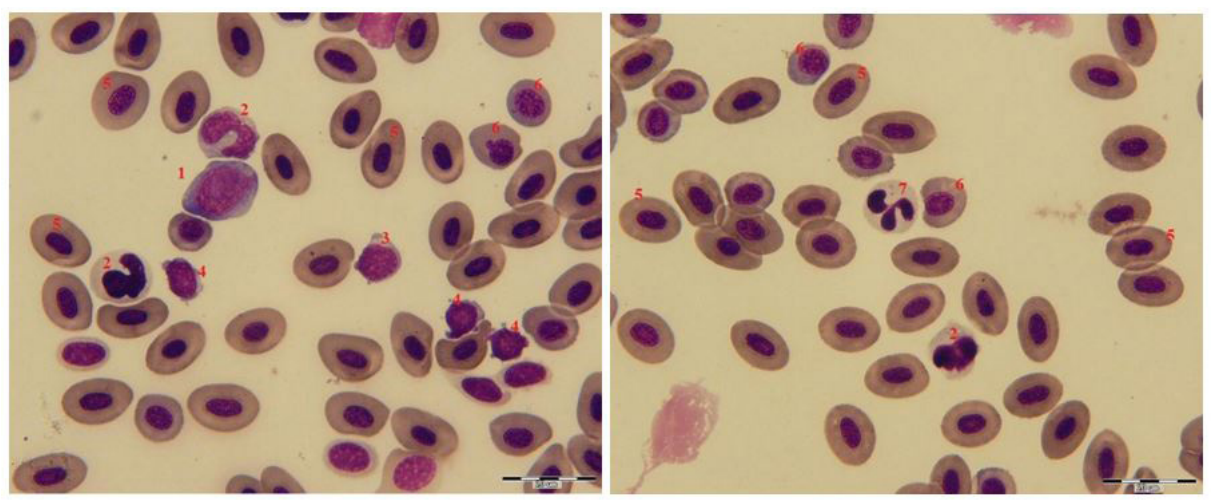

Figure 1. Peripheral blood cells of rainbow trout:1. Monocytes, 2. Non-segmented granulocytes, 3. Lymphocytes, 4. Thrombocytes, 5. Mature erythrocytes, 6. Immature erythrocytes, 7 . Segmented granulocytes. 
point out that those hematological parameters in different fish species are a significant indicator of the environmental stress [15].

Our results demonstrated significant changes in a large number of hematological parameters in the action of $\mathrm{NaOCl}$. Among the hematological parameters it is very important to emphasize the changes in the decreased hemoglobin concentration and the increase in the number of erythrocytes, as well as erythrocyte constants ( $\mathrm{MCV}, \mathrm{MCH}$ and $\mathrm{MCHC}$ ). Reduced hemoglobin level affects erythrocyte ripening due to which erythropoiesis is accelerated in the hypoxic reaction. This increases the number of erythrocytes, but their volume (MCV) is lower, as is the decrease in hemoglobin concentration $(\mathrm{MCH}$ and $\mathrm{MCHC}$ ). The value of $\mathrm{MCV}$ can indicate normal or abnormal cell division in the erythropoietic events, while $\mathrm{MCHC}$ is an indication of a reduction in hemoglobin synthesis [16,17]. Active chlorine can lead to changes in blood $\mathrm{pH}$ because ions of $\mathrm{Cl}^{-}$reduce the binding affinity of $\mathrm{Hb}$ for oxygen. Similar effects have been shown by the use of pesticides [18]. In many other applications, the use of certain chemical compounds has led to similar results, such as the Onchorhynchus mykiss, Tilapia mossambica, Ctenopharyngodon idella, while the number of erythrocytes decreases in Cyprinus carpio [18-21]. Biocidal efficacy of chlorine depends on the amount of hypochloric acid in the water, since it is able to penetrate the cells and react with the enzymes [6]. It is also reported that chlorine is dispersed by vascular scurvy surfaces and thus affects the central nervous system. Block [22] reported that such conditions lead to damage of the gills. Since dissolved oxygen is absorbed by the gills, glycine chlorine reduces the affinity of binding of oxygen to hemoglobin which causes hypoxia.

Further, $\mathrm{Cl}^{-}$ions in this case can further penetrate the erythrocytes and thus disturb the balance of ions, and the increased oxidative metabolism with additional acids causes acidosis [23]. Hemoconcentration present in hypoxia leads to the formation of reduced glutathione and plasma proteins that prevent the transport of oxygen to the tissue [16]. Brooks and Bartos [24] analyzed the time of exposure of free and combined chlorine to the Californian trout and found that free chlorine was 8-14 times more toxic than in some chemical compound. Many studies suggest that chlorine is not the primary cause of stress reaction [16]. An increase in the number of leukocytes, especially lymphocytes, is the result of a stressful reaction, as lymphocytes are very important blood cells in the immune defense. The number of leukocytes and differential blood count of leukocytes is an important indicator for non-specific defensive activities of fish [25]. Atamapal and Yanik (2007) reported an increase in the number of leukocytes due to poisoning [18]. Increase in the number of Iymphocytes in the stress reaction for ${ }^{1 / 4}$ was reported, as well as the action of xenobiotic $[26,27]$. The Californian trout is very sensitive to the presence of metal in water unlike other dominant species [28].

The values of $\mathrm{K}^{+}$and $\mathrm{Ca}^{2+}$ were reduced, suggesting a reduced heart rate. Zeraik et al. [15], reported that at the low concentration of residual chloride, hyperventilation and bradycardia in fish occurs due to hypoxia. Significant increase in $\mathrm{Cl}^{-}$ could be the result of a stress reaction, as well as the consequence of the additional absorption of chloride ions. If the fact of additional chlorine ion absorption is ignored, recent studies show that in addition to glucose, chlorine ions are a significant stress response indicator. In addition to this, studies were carried out in a various stress conditions such as temperature shock in the tench and the period of trout spawning $[29,30]$. Many studies on fish species have confirmed the glucose variations as a primary indicator of stress in fish $[31,32]$.

In addition to the above changes, major changes in the metabolism of proteins are evident. Increasing total protein concentrations cannot be interpreted as an increased protein synthesis in a stress reaction, as oxygen supply was reduced. Small urea concentration changes may indicate that protein degradation is very low. However, very large oscillations of creatine can only indicate reduced clearance in the kidneys, which can be a consequence of reduced glomerular filtration and blood flow through the kidneys. This is the method of elimination of excess ions formed in acidosis caused by the absorption of hydrogen and chloride 
ions, as well as in anaerobic conditions. Brooks and Bartos [24] reported that due to the action of chlorine, penetration of acid, acidosis caused by hypoxia, plasma albumin increases, which affects the total proteins.

Results obtained in the present study showed decrease in the concentration of $\mathrm{K}^{+}$and $\mathrm{Ca}^{2+}$ after chlorine exposure and increase in the concentration of the other parameters with highest variations for chloride and creatinine values. Regarding hematological parameters, an increase in erythrocyte and leukocyte counts as well as higher percentage of lymphocytes and monocytes were found in experimental group of fish. Small doses of $\mathrm{NaOCl}$ alter the acid-base balance, suggesting a very low-level adaption in the rainbow trout.

\section{References}

1. G. Nussey, J.H.J. Van Vuren, H.H. Du Preez, Effect of copper on the differential white blood cell counts of the Mozambique tilapia (Oreochromis mossambicus), Comp. Biochem. Physiol., 111 (1995) 381-388.

2. B.A. Barton, C.B. Schreck, Influences of acclimation temperature on interrnal and carbohydrate stress responses in juvenile chinook salmon (Oncorhynchus tshawytscha), Aquaculture, 62 (1987) 299-310.

3. G.P. Chrousos, Stressors, stress and neuroendocrine integration of the adaptive response, Ann. NY Acad. Sci., 851 (1998) 311-335.

4. G.L. Seegert, A.S. Brooks, J.R. Vande Castle, K. Gradall, The effects of monochloramine on selected riverine fishes, Trans. Am. Fish. Soc., 108 (1979) 8896.

5. J.A. Zillich, Toxicity of combined chlorine residuals to freshwater fish, J. Water Pollut. Control Fed., 44 (1972) 212-220.

6. E.W. Moore, Fundamentals of chlorination of sewage and waste, Harvard University, Harvard, USA, 1951.

7. D.H. Evans, P.M. Piermarini, W.T.W. Potts, Ionic Transport in the Fish Gill Epithelium, J. Exp. Zool., 283 (1999) 641-652.

8. D.R. Grothe, J.W. Eaton, Chlorine-Induced Mortality in Fish, Trans. Am. Fish Soc., 104 (1975) 800-802.

9. R.S. Ingols, H.A. Wyckoff, T.W. Kethley, H.W. Hodgden, E.L. Fincher, J.C. Hildebrand, J.E. Mandel, Bactericidal studies of chlorine, Ind. Eng. Chem. Res., 45 (1953) 996-1000.

10. I.H. Zeiutoun, The effect of chlorine toxicity on certain blood parameters of adult rainbow trout (Salmo gairdneri), Environ. Biol. Fishes, 1 (1977) 189-195.

11. J.R. Pratt, N.J. Bowers, B.R. Niederlehner, J. Cairns, Effects of chlorine on microbial communities in naturally derived microcosmos, Environ. Toxicol. Chem., 7 (1988) 679-687.
12. J. Mišovi, T. Ast, Instrumentalne metode hemijske analize, TMF, Beograd, Serbia, 1989.

13. M.L. Verso, The Evolution of Blood Counting Techniques, Read at a meeting of the Section of the History of Medicine, First Australian Medical Congress 8 (2013) 149-58.

14. P. Balasubramaniam, A. Malathi, Comparative study of hemoglobin estimated by Drabkin's and Sahli's methods, J. Postgrad. Med., 38 (1992) 8-9.

15. V.M. Zeraik, T.C. Belão, L.H. Florindo, A.L. Kalinin, F.T. Rantin, Branchial O(2) chemoreceptors in Nile tilapia Oreochromis niloticus: Control of cardiorespiratory function in response to hypoxia, Comp. Biochem. Physiol. A Mol. Integr. Physiol., 166 (2013) 17-25.

16. M.J. Zorriehzahra, M.D. Hassan, A.A. Saidi, Study of some hematological and biochemical parameters of rainbow trout (Oncorhynchus mykiss) fry in western part of Mazandaran province, Iran, Iran. J. Fish Sci., 9 (2008) 185-198.

17. V. Wepener, J.H.J. Vuren, H.H. Du Preez, Effects of manganese and iron at a neutral and acidic $\mathrm{pH}$ on the hematology of the banded tilapia (Tilapia sparrmanii), Bull. Environ. Contam. Toxicol., 49 (1992) 613-619.

18. M. Atamanalp, T. Yanik, Alterations in hematological parameters of rainbow trout (Oncorhynchus mykiss) exposed to mancozeb, Turk. J. Vet. Anim. Sci., 27 (2002) 1213-1217.

19. F. Aziz, M. Amin, A.R. Shakoori, Toxic effects of cadmium chloride on the haematology of fish, Tilapia mossambica, Proc. Pakistan Cong. Zool., 13 (1993) 141154.

20. A.R. Shakoori, A.L. Mughal, M.J. Iqbal, Effects on sublethal doses of fenvalerate (a synthetic pyrethroid) administered continuously for four weekks on the blood, liver and muscles of a freshwater fish, Ctenopharyngodon idella, Bull. Environ. Contam. Toxicol., 57 (1996) 487-944.

21. P.M. Reddy, M.D. Bashamohideen, Fenvalerate and cypermethrin induced changes in the hematological parameters of Cyprinus carpio, Acta Hydrochim. Hydrobiol., 17 (1989) 101-107.

22. R.M. Block, Physiological response of estuarine organisms to chlorine, Chesapeake Sci., 18 (1977) 158160.

23. D. Suljevi, L. Mehinovi, Fiziologija homeostaze, Faculty of Science, Sarajevo, Bosnia and Herzegovina, 2014.

24. A.S. Brooks, J.M. Bartos, Effects of free and combined chlorine exposure duration on rainbow trout, channel catfish and emerald shiners, Trans. Am. Fish Soc., 113 (1984) 786-793.

25. N. Pedro, A.I. Guijarro, M.A.L. Patioo, R.M. Alvarez, M.J. Delgado, Daily and seasonal variations in haematological and blood biochemical parameters of Nile tilapia Orechromis niloticus (L), Braz. Arch. Biol. Technol., 47 (2005) 945-953.

26. G. Peters, R. Schwarzer, Changes in hematopoietic tissue of rainbow trout under influence of stress, Dis. Aquat. Organ., 1 (1985) 1-10.

27. A. Thuvander, Cadmium exposure of rainbow trout, Salmo gairdneri Richardson: effects on immune functions, J. Fish Biol., 35 (1989) 521-529. 
28. K.A. Sloman, J.D. Armstrong, Physiological effects of dominance hierarchies: laboratory artefact or natural phenomenon?, J. Fish Biol., 61 (2005) 1-23.

29. J. Nowosad, D. Kucharczyk, T. Liszewski, K. Targo ska, R. Kujawa, Comparison of temperature shock timing to induced artificial mitotic gynogenesis and androgenesis in common tench, Aquac. Int., 23 (2015) 45-53.

30. Y. Güner, Z. Peker, M. Altunok, Optimization of Thermal Shock for Poliplody Induction in Rainbow Trout (Oncorhynchus mykiss) under Photoperiodic Control of Spawning, Turk. J. Fish Aquat. Sci., 16 (2016) 797-804.
31. L.A. Kioshi Aoki Inoue, G. Moraes, G.K. Iwama, L.O. Bertola Afonso, Physiological stress responses in the warm-water fish matrinxã (Brycon amazonicus) subjected to a sudden cold shock, Acta Amazon., 38 (2008) 603-610.

32. H.C. Cho, J.E. Kim, H.B. Kim, H.J. Baek, Effects of Water Temperature Change on the Hematological Responses and Plasma Cortisol Levels in Growing of Red Spotted Grouper, Epinephelus akaara, Dev. Reprod., 19 (2015) 19-24. 
